Center for

Economic Theories and Policies

Sofia University St. Kliment Ohridski

Faculty of Economics and Business Administration

ISSN: 2367-7082

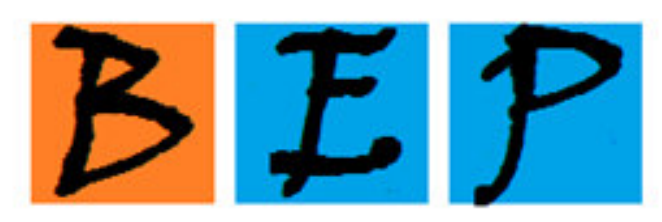

Bulgarian Economic Papers

\title{
Vamos a la Playa vs. Standing at the Gates: Beaches in Bulgaria
}

\author{
Henrik Egbert \\ Aleksandar B. Todorov
}

BEP 08-2016

Publication: October 2016 


\title{
Vamos a la Playa vs. Standing at the Gates: Beaches in Bulgaria
}

\author{
Henrik Egbert ${ }^{1}$ and Aleksandar B. Todorov ${ }^{2}$
}

October 4, 2016

\begin{abstract}
Beaches at the Bulgarian Black Sea coast were primarily a public good until the mid 1990s. By then the Bulgarian government granted private investors temporary property rights by providing concessions. Consequently, many beaches show characteristics of club goods nowadays. On a national level the process can be considered as a reallocation of public resources, thus affecting the well-being of many. This paper focuses on three aspects of this process and contributes to the ongoing discussion of how to handle public resources by addressing the case of beaches in Bulgaria. Firstly, we describe the process as it could be observed for beaches in Bulgaria in order to provide an analytical basis for further research. Secondly, stakeholders and their interests are identified. Thirdly, the paper points at conflicts between the different types of shareholders.
\end{abstract}

Keywords: common pool resource, club good, beach, beach management, licensing, Bulgaria

JEL: P26, R14, R38, Z32

\footnotetext{
${ }^{1}$ Dr. Henrik Egbert is Professor of Economics at Anhalt University of Applied Sciences, Germany. Contact: henrik.egbert@hs-anhalt.de.

${ }^{2}$ Dr. Aleksandar B. Todorov is Assistant Professor at the University of Economics Varna, Bulgaria. Contact: atodorov@ue-varna.bg.
} 


\section{Introduction ${ }^{3}$}

Tourists who wish to go to a beach on a hot summer day in Bulgaria find that plenty of beaches have restricted access. Many beaches are reserved for customers of specific establishments such as apartment complexes. The 'free beach', i.e. a beach that can be used by the public without restrictions, has become a rare case at the Bulgarian Black Sea coast as of 2016. About half of all beaches are rented out to private investors. This was rather different quarter of a century earlier.

At the end of the socialist period, 27 years ago, beaches in Bulgaria were, by and large, public goods. The criterion of non-excludability was applicable since unlimited access was given to the public. In certain periods of time rivalry in consumption occurred in the form of crowding, particularly noticeable during the summer season. The beaches were managed by the state authorities. Only some strips belonged to seaside resorts often used by the ministries, the police, the army or other former socialist organizations, where access was restricted.

An impure public good, such as a common pool resource, faces the problem of excessive usage since excludability is not given. In the case of beaches indicators of excessive usage are the degree of pollution of the beach and the sea, overcrowding, using the beach for business activities, or as a building ground. Additionally, excessive usage may damage related public goods, such as biodiversity. As traditional economic theory predicts, individual rational behavior may lead to inefficient outcomes for a society unless effective coordination mechanisms are implemented. This may also be the case with the use of beaches in Bulgaria.

A new allocation mechanism was introduced by the government in 1997. By the end of 2014, 54 percent of beaches in Bulgaria had been controlled by private companies (Ministry of Regional Development 2014). Large shares of the former public good had turned into club goods with the features of excludability but non-rivalry in consumption for club members. The switching from Vamos a la playa - our synonym for the beach as a public good - to Standing at the Gates - as our synonym for the beach as a club $\operatorname{good}^{4}$ - has been extensively commented in the Bulgarian media.

\footnotetext{
${ }^{3}$ For helpful comments on earlier drafts we thank Anton Gerunov, Martin Hoffstadt, and Teodor Sedlarski. For research assistance we thank Konstantin Kleemann. The usual disclaimer applies.

${ }^{4}$ Song title by the band Righeira in 1983 and song title by Garry Rafferty in 1982.
} 
The analysis of the case in a more detail is important since the case addresses one of the largest industries in the country, the tourist industry. This industry contributes about 7.7 percent to the Bulgarian GDP in 2013 (Eurostat 2014) and a large share is directly related to revenues generated at the Bulgarian Black Sea coast. Despite this significance for the economy, the specific topic of how the Bulgarian beaches are governed has not been analyzed by economists yet. Furthermore, to the best of our knowledge, the process of licensing has not been recorded, nor have there been studies on common pool resources where customers' willingness to pay has been measured in the country.

This paper examines the case and closes some of these gaps. We explore how the shift from a public good to a club good has been implemented and exercised, and we analyze the effects on stakeholders in this process. Furthermore, we elucidate the conflict between different types of investors in this process.

The case of Bulgarian beaches and their transformation from public goods into club goods have similarities to developments in other countries. For instance, as of 2015 most of Lebanon's coastline along the Mediterranean Sea has been privatized, i.e. it is managed by private developers, hotels and resorts, which in some cases charge the public up to 30 USD to access the beaches (Williams 2015). As part of its privatization program the Greek government is considering the privatization of a vast portfolio of state-owned assets including beach coastlines (Alexander 2013; Alderman 2015). The United States offer another example where each coast state has its own public policy regarding beach access ranging from extensive privatization (e.g., California) to a full open access on the entire coastline (e.g., Oregon). ${ }^{5}$

This case study of Bulgarian beaches is also relevant for other industries since it provides an example for the problem of managing public goods and, respectively, common pool resources. In order to show this we tackle three questions in this article:

(1) How has the change from a public to a club good been organized?

(2) How does this process affect stakeholders' rents?

(3) What conflicts occur among stakeholders in this process?

\footnotetext{
${ }^{5}$ The story of Oregon's "Beach Bill" and the controversy of the various interested parties is captured in a 2009 documentary by Tom Olsen, Jr. (cf. Olsen 2009).
} 
Based on these objectives the paper is structured as follows. Section 2 briefly reviews the literature with respect to the case study. In Section 3 we address the first question and illustrate the case in greater detail in order to initially describe the process. We also identify the stakeholders and discuss the effects of this process on stakeholders' rents. Section 4 focuses on the main conflict related to the process, i.e. a conflict between different types of investors. Finally, Section 5 concludes.

\section{Review of the Literature}

The literature relevant to this case study is related to at least two strands. The first one is the literature on public management of public resources, and, more particularly, the literature on the management of recreational areas or beach management (e.g., Micallef and Williams 2002). The second one is that of economic theories on public goods, common pool resources and club goods, respectively. Both strands are overlapping and both address the importance of the institutional setting for an effective and sustainable use of public resources. While the public management literature places the emphasis on questions of valuation and pricing of the public resource, the economic literature focuses more on ownership and governance structures. Next we briefly relate a variety of aspects of both strands to the beaches. Firstly, we outline the main problems related to the management of public resources, and, secondly, we discuss proposed and applied solutions.

State management of public goods seems to be justified by externalities that may occur when specific types of public goods are consumed. A common pool resource is a case in point. Common pool resources are a specific type of public goods and show non-excludability of use but subtractive benefits for users. If an individual consumes the resource, less of the resource remains for other consumers. That is why common pool resources are subject to congestion, depletion or degradation (Gordon 1954; Randall 1983). The effective management of common pool resources is vital for societies (e.g., Agrawal 2003).

Beaches are exposed to at least two of the classical problems encountered in the economics of common pool resources, i.e. excessive usage and free riding. Since the number of beaches, respectively space, is limited, beaches should be used to a maximum current output. However, today's usage should not endanger the quantity and quality of the resource for future users. 
This argument holds even if the beach does not only have a recreational value but also an ecological value (Tratalos et al. 2013).

The problem of excessive usage could arise in situations of overcrowding or overbuilding. Indeed, many tourist resources are congestible goods, i.e. they are non-rival at levels between zero and some positive number of users, but they are rival if the number of users reaches a threshold. However, with respect to beaches, congestion cannot be simply viewed as a synonym for crowding which generates negative utilities. For some beaches users utility may increase with the number of visitors.

Another problem is resource damage due to excessive use. An example is provided by Morgan (1991). Majorca, once a fashionable destination for tourists, has become successively overcrowded and overbuilt as more and more investors applied an all-inclusive business model. Healy (1994) hypothesizes that beyond a certain number, an additional beach visitor contributes negatively to a local tourist sector. This view seems to be consistent with Butler's (1980) theory of the 'tourism cycle'. As other goods, tourism in a given area develops in stages, i.e. exploration, involvement, development, consolidation, and stagnation. During the early stages the number of visitors rise, new facilities and infrastructure are built, economic benefits increase, sometimes at the expense of environmental and social issues though (Tratalos et al. 2013). Toward the latter stages the area becomes highly developed and commercialized and economic benefits start to decline. Marinov (2012) uses the tourism cycle for the Bulgarian coastal tourism and concludes that Bulgaria gradually lost its competitiveness in the international market for coastal tourism in the late 1980s.

Besides crowding and excessive usage, common pool resources face the problem of underinvestment. For instance, Healy (1994) argues that an investment incentive problem may exist because non-investors are able to free ride and enjoy many of the benefits of quality enhancement initiated by investors. If there is non-excludability, free riding is a rational choice of users and for investors it is rational not to invest in the quality of the resource. Underinvestment in a resource may also occur if private property rights on the resource are granted only temporarily. In this case a rational choice of a private owner is to use the resource excessively as long as they have the right to do so. Incentives to preserve the resource for future owners are missing. 
There are numerous solutions to these problems. While the discussion in economics is related to New Political and New Institutional Economic Theory and focuses on ownership and governance structures, the business and management literature has put a strong emphasis on valuation and pricing options. We consider the ownership/governance structure as a first-level solution and a change in the ownership structure can already help to overcome specific problems of common pool resources. The finding and implementation of suitable valuation and pricing structures can be considered a second-level solution, since valuation and pricing depends on the type of good and ownership. Next, we discuss some aspects related to the first level. These aspects have a long tradition in economic theory and have become popular through the seminal works of Tiebout, Buchanan, and Olson.

Institutional change addresses ownership structures, i.e. property right structures in a society. ${ }^{6}$ As a consequence of an institutional change of property right structures, goods may change their characteristics, for instance from non-excludability to excludability. In order to prevent the excessive usage of a common pool resource three proposals for an institutional change have been made. The first approach addresses the establishment of full private property rights over the common pool resource (Demsetz 1967). The second relates to providing an external party - usually the state — with full authority to regulate the commons (Hardin 1968). The third follows Olson (1965). It addresses the 'logic of collective action' and implies action of several individuals who intend to achieve a common goal or the satisfaction of a common interest (e.g., Wade 1987). For simplicity reasons we can refer to these ownership structures as private, state, and interest groups. The third proposal assumes that common interests exist, and that individuals have the capacity to articulate these interests and goals. While this third proposal may be useful for relatively closed communities (e.g. Agrawal and Goyal 2001; Beem 2007; Feeny et al. 1990; Galappaththi and Berkes 2014; Libecap 2005; Makino and Matsuda 2005), for beaches which are frequented by local and foreign visitors it is unlikely that common goals can be formulated and articulated in public. That is why we focus on the 'private' and 'state' solution (cf. also Libecap 2005 for hybrid solutions).

The first solution changes the nature of the good itself because the resource becomes a private good. If there is a market, the good can be traded at prices that reflect scarcity. The management decision and the one whether to introduce a pricing mechanism or not is at the discretion of the private owner. The second solution leaves the management and the pricing

\footnotetext{
${ }^{6}$ See also the more recent discussions in the field of economic analysis of law and legal norms (Posner 2014).
} 
decision with the 'state'. The latter can be understood as a government plus subordinate organizations, often on a local level. For representatives of the state in a democracy, for instance politicians, introducing prices or other access restrictions to a common pool resource can be particularly challenging, since users may not honor positive prices for common pool resources in future elections.

With respect to beaches, private owners who have full property rights can solve the crowding problem in different ways. They can forbid or restrict beach access. If access is restricted for specific consumer groups, the former common pool resource becomes a club good (see Buchanan 1965; Sandler and Tschirhart 1997). Following the discussion on club goods, insights can be gained for the management of beaches. These goods are private in nature and individuals can be excluded. Club membership is obtained by entrance fees, specific nationality/ethnicity, age, or through buying a bundle of goods (e.g., hotel stays plus beach access). Thus, the management of beaches as clubs can solve some of the problems of common pool resources.

One can continue this line of thought with Tiebout's (1956) famous notion of 'voting with the feet'. If different clubs offer heterogeneous goods, consumers vote with their feet and choose clubs according to their preferences. This also holds if beaches and related services are offered as club goods. If these clubs are profit-oriented, however, and operate in imperfect competition, the equilibrium price typically tends to be higher than the competitive price (Scotchmer 1985; Scotchmer 2002, 7), thus resulting in inefficiency.

As we have mentioned, for private owners and for the state it remains essential to introduce an effective pricing mechanism. In order to be able to introduce a price, the economic value of the beach, its related services and its value as a natural coastal resource has to be measured. Since markets for such goods do not or only partially exist, non-market values such as recreation activities, sports facilities, space, or biodiversity have to be measured. We address this second-level solution next.

For the valuation of recreational areas including beaches a variety of tools and methods have been used. Most of the methods aim to calculate the demand and the willingness to pay for recreational areas. They include methods measuring revealed preferences or stated preferences (e.g., questionnaires, choice experiments, travel cost methods), methods that 
measure the economic impact of the resource (e.g., financial studies), or methods that evaluate beach related assets (e.g., developments on the housing markets). These different approaches and tools can be used complementarily (Whitehead et al. 2008; Massiani 2013, 89-92).

Blackwell (2007) measures the consumer surplus of beach visits by a valuation of the recreational beach visits in Australia. He applies the travel cost method in which beach users are asked to state their preferences (see also Raybould and Lazarow 2009). Results are compared with those for other recreational areas. Blackwell $(2007,95)$ finds that the maintaining and enhancing of beach services requires comparatively high government inputs. In a study on beaches in North Carolina (USA) Whitehead et al. (2008) apply a stated and revealed preference approach and hint at possible biases in the estimations. Birdir et al. (2013) use a willingness to pay method for Turkey and provide a short survey of recent studies (2013: 280). Dall'Aste and Marzetti (2009) use a stated preference approach for a beach in Italy in order to test the income and the number of visits as related to the recreational value (cf. also Marin et al. 2009). Oh et al. (2010) provide another recent study working with preference approaches. They compare resident and tourist preferences for public beach access and other amenities in South Carolina (USA) beach destinations using a stated preference choice methodology. The overall results suggest that tourists are more interested in additional public beach access points and commercial development, while residents support beach rules and regulations but oppose high levels of crowding and noise (see also Blackwell 2007). As an alternative to the travel method Windle and Rolfe (2014) use a valuation experiment to estimate the willingness-to-pay of focus groups in Brisbane (Australia). In order to determine the beach value to the Italian society, Massiani (2013) uses a cost-benefit analysis. Specific in his study is that the potential beach visitors are most likely residents and not tourists. He shows that a contingent valuation together with a pressure-intensity function can be useful methods for determining values.

If one uses the carrying capacity, i.e. definitions with respect to the optimum number of visitors per area, results show differences between physical and social carrying capacities. For instance, Zacarias et al. (2011) assess the optimum number of individuals that should be allowed to a beach area to Praia de Faro (Portugal). Their results indicate that while the physical carrying capacity is estimated between 1,491 and 2,982 visitors per day, the social capacity of the beach is estimated to be only 305 visitors per day for local inhabitants and 608 for tourists. 
This brief survey illustrates that different valuation methods for beaches and related services exist. One can conclude that the willingness to pay for beach usage and related demand functions can be estimated for residents as well as for non-residents. However, the literature does not provide much information when it comes to the practical implementation of prices for beach usage. Only few studies report implementations of pricing mechanisms. Whitehead et al. (2008) address the prerequisites for cost sharing between the federal level and local communities for beach re-nourishment projects in the US. Anderson et al. (2015) name and discuss possible implementations in order to curtail over usage, i.e. raising parking fees and introducing beach taxes. For Bulgaria, to the best of our knowledge, there are no studies that report a valuation of beaches. In the next section we provide a description of the case. It allows identifying different stakeholders.

\section{Bulgarian Beaches: From Socialism to Capitalism}

Until 1990 Bulgaria was an integral part of the socialist block (1945-1990), where restrictive national and international travel regulations applied. Bulgarian beaches on the Black Sea coast were provided as public goods with the exceptions of those pitches of land which were used by state organizations - the so called bazi. These pitches were frequented by civil servants and state officials (and their families), e.g. by employees of a ministry, a state-owned company, the police, or the fire fighters. Bazi were already clubs in the socialist era. Nevertheless, many beaches in socialism had no restrictions for visitors, locals and tourists alike.

The political changes in the early 1990s brought about fundamental shifts in the Bulgarian society. The planned allocation of goods was gradually replaced by a market-oriented allocation. After a period of experimental petty capitalism (Konstantinov et al. 1998; Egbert 2006; also Ganev 2014), the privatization of state property (Mladenova \& Angresano 1996; Miller \& Petranov 2000) and a period of substantial social and economic turmoil indicated by periods of hyperinflation, the economy started stabilizing after 1998 (cf. also Chobanov \& Egbert 2007). This was largely due to the introduction of a currency board in 1997 so that monetary stability occurred after a period of substantial economic and social unrest. A landmark in this process of economic stabilization and development was the country's EU accession in 2007. 
With the turn from a socialist to a market economy and with the economic stabilization in 1998, national and international demand for a place on Bulgarian beaches increased. This is illustrated in Figures 1 and 2. Figure 1 provides the number of tourists and the number of nights that tourists spent in Bulgaria, while Figure 2 shows the dynamics in accommodation establishments (number of hotels and beds) development from 1990 to 2014.

\section{Figure 1: Number of tourists and of nights spent by tourists 1990 to 2014}

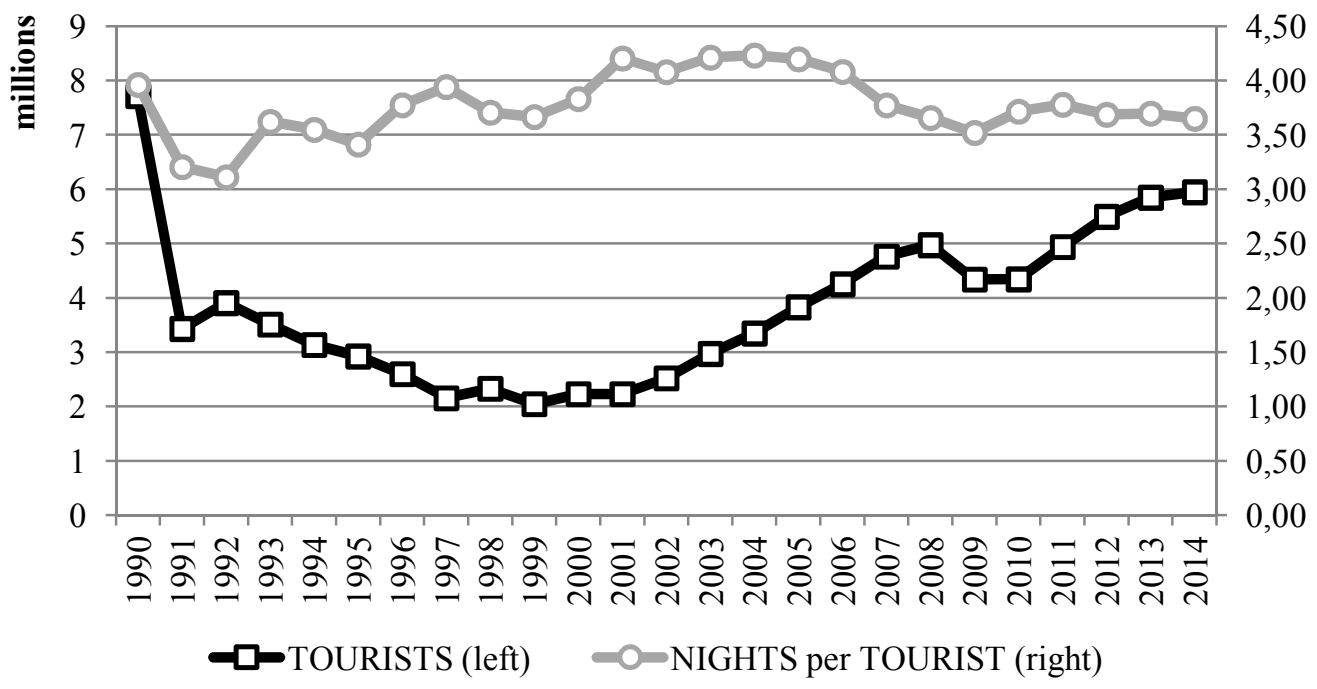

Source: Own presentation based on EUROSTAT 2014.

Figure 2: Number of hotels and beds 1990 to 2014

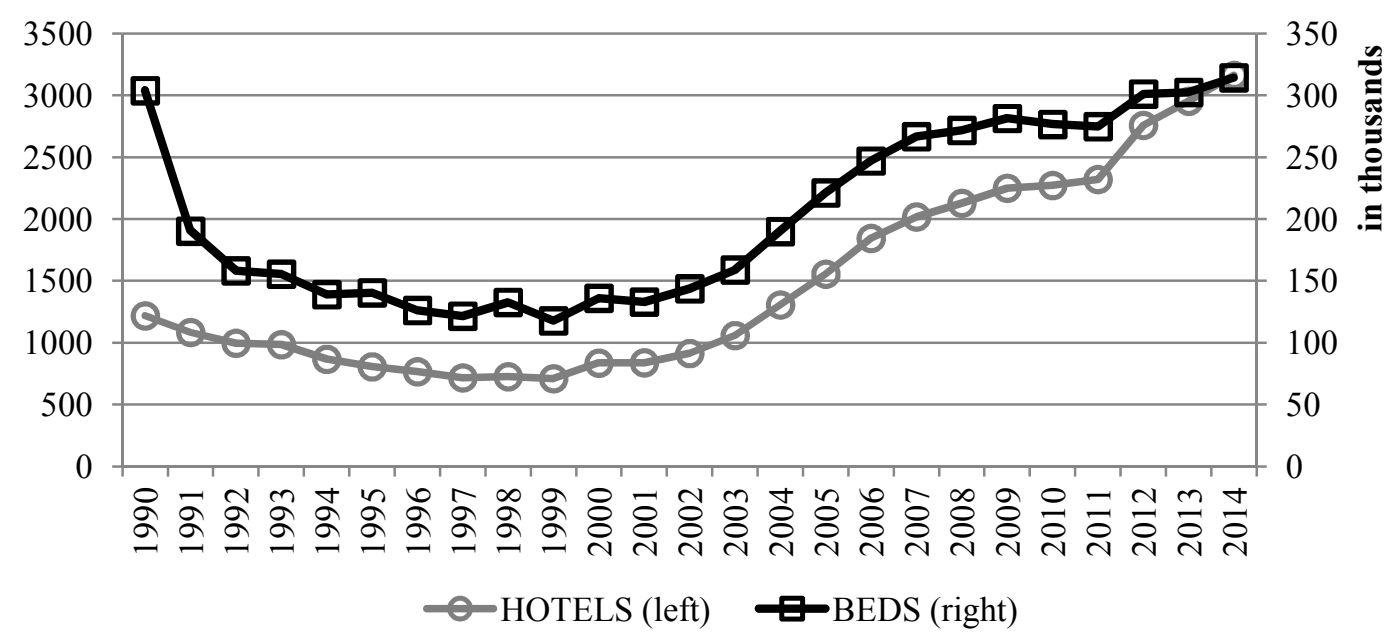

Source: Own presentation based on EUROSTAT 2014. 
Figure 1 illustrates the strong decline of tourists (left axis) and also of the nights spent by tourists in Bulgaria (right axis) for the years 1990 to 1992. From 1990 to 1999 the number of tourists dropped from 7.7 million to slightly more than 2 million annually, i.e. a drop of $74 \%$ percent. For the following years the graphs illustrate a steady increase for both indicators, interrupted in 2009 and 2010 due to the effects of the world economic crisis. Figure 2 demonstrates an upsurge of the number of hotels and beds after 1997, which was driven mainly by the construction of new accommodation establishments on the Black Sea shore.

The remaining of this section illustrates the process from Vamos a la playa to Standing at the Gates. Bulgaria has a coastline with a length of $378 \mathrm{~km}$, on which there are 207 beaches or about 16,000 acres of beach area (Marinov 2012). These figures are small in comparison to those of neighboring Greece or Turkey. Nevertheless, for decades summer tourism in Bulgaria has brought considerable revenues to the seaside municipalities, to businesses, and to the national state budget. Almost the entire country's coastline is involved in tourism. This public resource, on which according to the Bulgarian constitution the State enjoys exclusive ownership (Article 18(1) of the Constitution of the Republic of Bulgaria), generates rents, taxes and other fees, but requires at the same time almost the same amount of investment in maintenance and service (Leshtarska 2015).

The process of transferring Bulgarian beaches to private investors began in 1997, i.e. the year of monetary stabilization. Since then many of Bulgaria's coastline beaches have passed into the hands of private investors. In this paper we distinguish between two types of private investors:

- Type I investors are owners of hotels, who manage beaches adjacent to their establishments thus providing complete service packages to their clients.

- Type II investors are tenants of beaches aiming to profit from tourists staying in local hotels or random visitors of local restaurants and shops.

Indeed, 'the state', i.e. the national government, is the first level gatekeeper or principal. An investor, or agent, needs a special license in order to commercially operate a beach. This is provided as a concession issued by the Ministry of Regional Development for a maximal period of 20 years (Art. 8 \& Art. 7(1) of the Act on the Black Sea Coast Spatial 
Development). ${ }^{7}$ The Minister of Regional Development can also enter into a rental contract with an investor, if there is no sufficient interest in a concession, whereby the rental contract has a duration of no more than 5 years after which the contract has to be renewed or a new concession procedure has to be initiated (Art. 7(5) of the Act on the Black Sea Coast Spatial Development).

Additionally, the Minister can transfer her rights for entering into a rental agreement to the district governor who can then enter a rental contract for a beach in her district (Art. 7(6) of the Act on the Black Sea Coast Spatial Development). If there is no investor interest in a particular beach, then the Minister declares this beach as unprotected (Art. 7(7) of the Act on the Black Sea Coast Spatial Development). Figure 3 illustrates the allocation process of beach contracts and the revenue streams from these contracts.

Figure 3: Allocation of Beaches in Bulgaria according to the Act on the Black Sea Coast Spatial Development (ABSCSD), 2015-2016

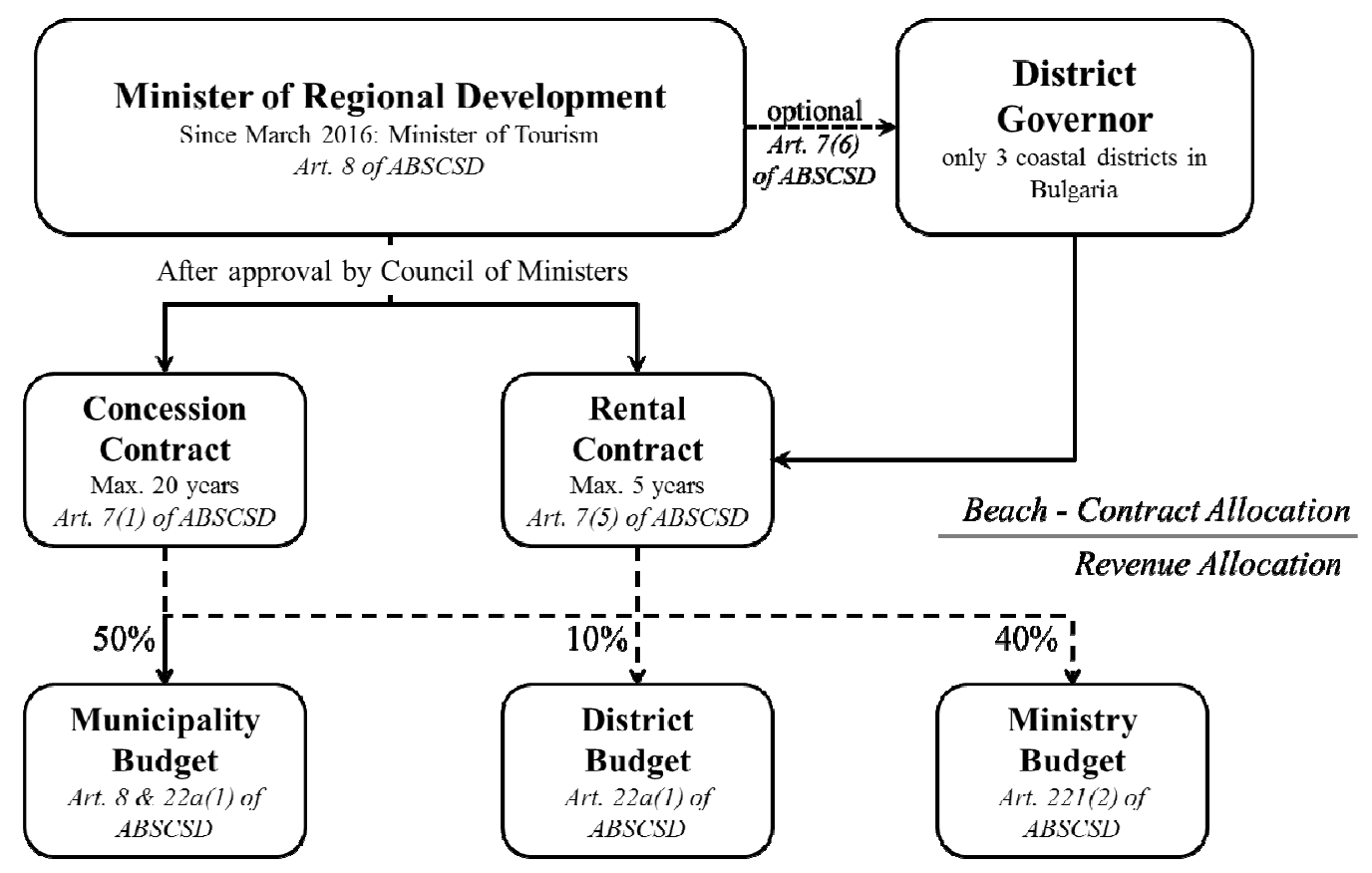

Source: Own presentation based on the Act on the Black Sea Coast Spatial Development (ABSCSD).

7 As of March 2016 the concessions are issued by the Ministry of Tourism. The allocation mechanism, however, remains unchanged, as described above. 
At the beginning of 2016 the Ministry of Regional Development issued concessions according to the above described procedure for most of the commercially operated beaches -55 out of 118 in total (see Table 1). There are also 44 beaches that are rented by the Ministry and 17 beaches that are rented by district governors, while only 2 beaches are operated by municipalities. This gives a total figure of 118 commercially operated beaches in 2016, which is about $60 \%$ of all beaches. For the other $40 \%$ of the beaches no concessions or rental contracts are issued.

Table 1: Number of contracts for commercial beach usage in 2015 and 2016

\begin{tabular}{|lr|r|}
\cline { 2 - 3 } \multicolumn{1}{c|}{} & 2015 & 2016 \\
\hline Concessions granted by the Ministry of Regional Development & 56 & 55 \\
\hline Rental contracts with the Ministry of Regional Development & 43 & 44 \\
\hline Beaches operated by municipalities & 21 & 17 \\
\hline Total & 2 & 2 \\
\hline
\end{tabular}

Sources: Data for 2015 is provided by Pavlova (2015); data for 2016 is provided by the Ministry of Regional Development upon request by the authors in February 2016.

According to the Act on the Black Sea Coast Spatial Development 50\% of the revenues from the concession and rental contracts are to be transferred to the municipality budget, to which the particular beach belongs, $10 \%$ of the revenues are to be transferred to the respective district and the remaining $40 \%$ are transferred to the ministry budget (Articles $8(2)$ and $22 \mathrm{a}(1)$ $\&$ (2) of the Act on the Black Sea Coast Spatial Development). According to Article $8 \mathrm{~d}$ of the same Act, the Minister of Regional Development provides to the Council of Ministers a grounded proposal for awarding a concession for a particular beach. The proposal includes the terms and purpose of the concession, a description of the services and activities, which are to be carried out at the concession site among others. If a concession is obtained, investors are allowed to place beach facilities, by providing no less than $50 \%$ of the active beach area for free placement of beach facilities on behalf of the visitors, so called "free zone" (Article 10(3) of the Act on the Black Sea Coast Spatial Development).

For all applicants the same rules apply, regardless of the location of the beach and regardless of the type of investor, i.e. both types I and II have to apply either for a concession or a rental contract in order to operate a beach commercially. New concessions for beaches which are not under commercial use are issued every 12 months. The complete annual fee is to be paid 
upfront by the concession holder regardless of how long she is planning to operate the beach during the year and independent of her business success. For instance, if the beach has to be closed for some reason, such as water pollution, then the concession holder bears all costs, and thus all risks. Additionally, the concession holder has to cover all maintenance costs such as beach rescue, medical assistance, beach cleaning, and technical infrastructure. The rules are equally set for both types of investors and for all types of beaches.

After receiving a concession the investor becomes a second-level gatekeeper of the particular beach. The investor is free to decide on the revenue streams that are to flow into the business venture. Most of the investors prefer mixed sources of revenue. For instance, they charge all parties that would like to have access to the particular beach, such as tourists, local restaurants and shops, as well as hotels. Tourists pay for sun-shades and sun-beds and other comforts, restaurants and shops pay either fixed rents or split profits with the investor. These local businesses often have only short term contracts leaving an option for the investor to exit the relationship. Nearby hotels negotiate contracts with the investor. From these revenues the investor's costs for providing services such as medical assistance and beach safety are to be deducted.

\section{The Principal, Heterogeneous Agents and Conflicts}

In this section we identify the stakeholders and discuss their incentives set by the change of ownership. Our focus is on the main conflict that has resulted as a consequence of the new allocation mechanism since the mid 1990s. The conflict is relevant because it causes costs and hampers efficiency. In order to elucidate this problem we use a principal-agent approach and show the different interests of type I and type II investors. These investors can be considered to be heterogeneous agents employed by a principal (for heterogeneous agents see, e.g., Levy and Vukina 2002). The latter is a government, represented by an administrative unit, e.g. a ministry.

There are two limitations in the following discussion. Firstly, the effects can be quantified only to a very limited degree since valuations of beaches and related services are presently absent. Secondly, changing a status quo by implementing new institutional structures implies redistribution effects thus addressing normative issues. A new assignment of property rights 
to new groups induces redistribution effects and implies the exclusion of individuals and groups who previously derived utility from using the resource (Libecap 2005: 549).

The most important stakeholders that we have identified are the first- and second-level gatekeepers, i.e. (a) the state, (b) type I, and (c) type II investors. Other stakeholders, such as tourists and local businesses largely depend on these gatekeepers. Recently, the environmental movement in Bulgaria emerged as a new stakeholder and articulated, partly successfully, interest in beach preservation. Lobbying of this stakeholder influences the strategic behavior of the other ones but is not a subject of this paper. Next we discuss the three central stakeholders and presently observable conflicts.

(a) The state represented by the government and politicians can be considered the principal. Since the government derives benefits by issuing concessions, politicians can communicate positive effects of this process in the political agenda. These effects are additional state revenues (see Table 2).

Table 2: Concession and fines revenue from the operation of beaches, 2013 to 2015

\begin{tabular}{|l|r|r|r|}
\hline Year & Total Revenue & Concession Revenue & Fines Revenue \\
\hline 2013 & 13636055 & 6827651 & 1289864 \\
\hline 2014 & 13573732 & 5697438 & 1268686 \\
\hline 2015 & 13845605 & 5396616 & 1554867 \\
\hline
\end{tabular}

Notes: All values are in BGN, $1 \mathrm{BGN}=0.51$ EUR. Data on total revenue is provided by the Ministry of Regional Development upon request by the authors in February 2016. The data on concession revenue and fines revenue stems from the annual report of the Ministry for Regional Development.

In Table 2 the column "Total Revenue" represents aggregate revenues from concession and rental contracts transferred to the accounts of the Ministry of Regional Development. As suggested in Figure 3 these are only about $40 \%$ of the total contract revenues. The second column "Concessions Revenue" contains revenues from concession contracts only. The column "Fines Revenue" provided in Table 2 includes primarily fines on investors who have violated laws in some way, e.g. they have not provided beach safety. This section includes also fines which are not related to beach operation and were imposed by the Ministry. That is why the numbers are higher than those of beach related fines. We found that more detailed statistics on beach operation in Bulgaria are hard to obtain. 
(b) Type I investors are in our classification hotel owners or owners of beach complexes. They offer an integrated service, e.g. hotel rooms, spa or golf resorts plus beach access to their customers. Type I investors hold large resorts mostly famous from the socialist time, such as Golden Sands, Sunny Beach and Albena. In order to be able to provide an integrated service, the beach area is part of their service portfolio and beach access is incorporated into the offered bundle. It is reasonable to assume that these investors invest comparatively large amounts, for instance in building and operating the necessary infrastructure as well as the general management and marketing of the provided services. In order to make these investments profitable, type I investors rely on returning customers and on offering services, for which customers have a willingness to pay. Therefore, beach areas operated by type I investors are expected to be governed as an integral part of their overall portfolio although access to the public may be restricted. The interests of type I investors are different from those of the second type.

(c) Type II investors are specialized beach operators, i.e. they have a concession or a rental contract for only a particular beach or a number of beaches in the same or in various coastal zones. These investors range from large and diversified companies and wealthy people to local investors. Considering these characteristics it could be expected that the direction and style of beach management is in the hands of the investor, who is to decide how the beach area to be governed. That includes decisions regarding the access to the beach, price setting and the type of infrastructure to be provided. These investors try to minimize costs, for example, by providing only the minimum required infrastructure, and to maximize revenues, for instance by charging as many parties as possible the highest feasible price. This is possible because they do not depend on customers who return year by year. Another strategy of these investors is to diversify the risk among the various sub-contractors, e.g. cafes, restaurants, schools for sport activities, wellness services and other businesses which are allowed to operate on the beach.

Given these different business strategies and incentives, it is not surprising that conflicts between type I and type II investors occur. The colliding interests become evident each time, when a discussion regarding the rules for the commercial operation of beaches becomes public. For instance, type I investors have claimed recently that they should operate as a whole one unit. Therefore 'the state' should transfer them the accompanying beaches instead of issuing concessions in a competitive mode. As an example the Union of Owners - Sunny 
Beach, a large professional organization of hotel operators on the Southern Black Sea coast in our classification type I investors - claims that the current procedure is not adequate as it leads to lowering the value of the product that hotel owners provide. Therefore, according to the claim, this procedure has to be transferred from the Ministry of Regional Development to the Ministry of Tourism, which would then act more strategically regarding the beach tourism industry than its predecessor (Union of Owners 2015). On the other side, the Association of Concessionaires of Beaches in Bulgaria, which at least partly represents type II investors, claims that the rules and the concession allocation procedure opens the gates to the beaches in Bulgaria only for a small portion of all potential competitors and is one of the main determiners of the price for end consumers (Stefanov 2015).

These conflicts, induced by the different strategic objectives of the agents, are supplemented by another type of conflict, which is innate to the contract allocation system. The latter conflict results from the different incentives provided by the institutional rules set by the concession contract on the one side and the rental contract on the other. This is evident in the different pricing systems used under the different types of contracts. For example, on July $20^{\text {th }}, 2015$ the Minister of Regional Development and other controlling agencies initiated a monitoring on 99 out of the 114 beaches under concession and rental contracts (see Table 1, column for 2015). The objective of the monitoring was to ascertain any violations of the obligations provided by the Act on the Blacks Sea Coast Spatial Development. The monitoring included also a collection of detailed price data on shades and chaise lounges for the particular beaches. Such information is relevant as concessionaires and tenants are not allowed to restrict access to a particular beach, but are obliged to provide at least $50 \%$ of the beach area as a free zone. So they charge for such services, instead of beach access. Beach visitors, who refuse to pay for comfort, are asked to use the free zone.

From an economic perspective it is to be expected that beach operators with a concession would have different incentives from those operators with a rental contract. In our classification scheme, for example, type I investors are expected to use an allocation mechanism with a long-term perspective, i.e. a concession contract, while type II investors are expected to use the short-term option, i.e. a rental contract. Allocating the two types of investors to a particular contract scheme is not as easy as it seems, because type II investors may also apply for a concession. The reason is that initially the most attractive beaches are 
offered by the Minister under this scheme and only afterwards, if there is no sufficient interest on the side of investors, the beach is offered for a rental contract.

We use the price data provided by the Ministry of Regional Development in order to test different pricing systems under a concession and a rental contract (Pavlova 2015). The monitoring included in total 56 beaches with a concession and 43 beaches with a rental contracts. For these beaches detailed price data for shades and chaise lounges are reported separately. In some cases, however, prices are available only for both services together as beach operators provide them only as a bundle. We computed the total price for shades and chaise lounges and compared the average prices for both types of contracting. Our calculation shows that on average beach comfort (shade plus chaise lounge) is priced at 11.43 BGN under a concession contract, and at 14.26 BGN under a rental contract. This difference in average prices is significant $(t=-2.127, p=0.036)$. So pricing under the concession contract seems to be somewhat lower than under the rental contract. This example illustrates that the two types of investors follow different business and pricing strategies and that conflicts are likely to persist in the future, thus hampering the effectiveness of the new allocation system.

\section{Conclusion}

This paper provides the first study on some effects of licensing beaches in Bulgaria. In this survey we elucidate how the provision of concessions and rental contracts have turned a formerly public good into a club good with private investors as gatekeepers. Beside the description of the process we identify the most important stakeholders in this process.

Since concessions and rental contracts allow investors to exclude users from the resource, a new distribution of wealth takes place in a society through the political process (Libecap 2005: 549). Rent seeking is likely to occur if considerable rents are to be expected. A related problem visible in the Bulgarian media is conflicts between different types of investors. These conflicts in concessions and rental contracts may negatively influence the effectiveness of the new institutional arrangements.

However, as a consequence of the redistribution of property rights, efficiency for the society may increase even if for some stakeholders utility losses occur. For instance, access restrictions to beaches can be considered a utility loss for tourists and local inhabitants. The 
quantitative effects of the new allocation mechanism are recorded only scarcely and data is hardly available. The same applies to the effects of this redistribution on social welfare.

For the latter it can be argued that losses for some stakeholders may hypothetically be compensated through the gains of the winners. Such a Kaldor-Hicks approach may be helpful in a long-time perspective. In the short run, the government and the concession holders classified in the text as type I and type II investors are the winners. The government receives revenues and decreases its costs of managing beaches and the investors are able to realize revenues and profits.

The study is limited with respect to quantifying revenues and utilities of different actors. This represents an option for an extension of the present study in the future if more quantitative data becomes available. For instance, the willingness to pay on the side of different stakeholders, e.g. local residents and tourists, could be measured through methods already applied to other beaches. Finally, the case is relevant for learning processes, particularly on the consequences and possible conflicts of providing licenses for former public goods in the country. Cases at hand are licensing private transport (taxis) or ski resorts. The study can be considered as an impetus for gaining more insights in the exploration of public and club goods and their societal impact in the country.

\section{References}

Agrawal, A. 2003. Sustainable governance of common-pool resources: Context, methods, and politics. Annual Review of Anthropology 32: 243-262.

Agrawal, A., Goyal, S. 2001. Group size and collective action: Third-party monitoring in common-pool resources. Comparative Political Studies 34(1): 63-93.

Andersson, K., Brierley, N., Hedstroem, F., Herr, D., Risson, J. 2015. Managing Congestion on Gold Coast Beaches: An Economic Evaluation. Griffith University (Discussion Papers in Economics 2015-04).

Beem, B. 2007. Co-management from the top? The roles of policy entrepreneurs and distributive conflict in developing co-management arrangements. Marine Policy 31(4): 540-549. 
Birdir, S., Ünal, Ö., Birdir, K., Williams, A.T. 2013. Willingness to pay as an economic instrument for coastal tourism management: Cases from Mersin, Turkey. Tourism Management 36: 279-283.

Blackwell, B. 2007. The value of a recreational beach visit: an application to Mooloolaba Beach and comparisons with other outdoor recreation sites. Economic Analysis \& Policy 37(1): 77-98.

Buchanan, J.M. 1965. An economic theory of clubs. Economica 32(125): 1-14.

Butler, R.W. 1980. The concept of a tourist area cycle of evolution: Implications for management of resources. Canadian Geographer 24(1): 5-12.

Chobanov, G., Egbert, H. 2007. The rise of the transaction sector in the Bulgarian economy. Comparative Economic Studies 49(4): 683-698.

Dall'Aste, B., Marzetti, S. 2009. Recreational demand functions for different categories of beach visitor. Tourism Economics 15(2): 339-365(27).

Demsetz, H. 1967. Toward a theory of property rights. American Economic Review. Papers and Proceedings 57(2): 347-359.

Egbert, H. 2006. Cross-border small-scale trading in South-Eastern Europe: Do embeddedness and social capital explain enough? International Journal of Urban and Regional Research 30(2): 346-361.

Eurostat 2014. Statistics explained: Tourism statistics. URL: http://ec.europa.eu/eurostat/ statistics-explained/index.php/Tourism_statistics (retrieved: 3.11.2015).

Feeny, D., Berkes, F., McCay, B.J., Acheson, J.M. 1990. The tragedy of the commons: Twenty-two years later. Human Ecology 18(1): 1-19.

Galappaththi, E.K., Berkes, F. 2014. Institutions for managing common-pool resources: The case of community-based shrimp aquaculture in Northwestern Sri Lanka. Maritime Studies 13(1): 1-16.

Ganev, V.I. 2014: The Borsa: The black market for rock music in late Socialist Bulgaria. Slavic Studies 73(3): 514-537.

Gordon, S.H. 1954. The economic theory of a common-property resource: The fishery. Journal of Political Economy 62(2): 178-203.

Hardin, G. 1968. The tragedy of the commons. Science 162(3859): 1243-1248.

Healy, R. 1994. The "common pool” problem in tourism landscapes. Annals of Tourism Research 21(3): 596-611.

Konstantinov, Y., Kressel, G., Thuen, T. 1998. Outclassed by former outcasts: Petty trading in Varna. American Ethnologist 25(4): 729-745. 
Leshtarska, D. 2015. The battle for the sea sand. Capital 33: 8-9.

Levy, A., Vukina, T. 2002. Optimal linear contracts with heterogeneous agents. European Review of Agricultural Economics 29(2): 205-217.

Libecap, G. 2005. State regulation of open-access, common-pool resources, in C. Menard and M. Shirley (eds), Handbook of New Institutional Economics. Dordrecht: Springer, $545-572$.

Makino, M., Matsuda, H. 2005. Co-management in Japanese coastal fisheries: Institutional features and transaction costs. Marine Policy 29(5): 441-450.

Marin, V., Palmisani, F., Ivaldi, R., Dursi, R., Fabiano, M. 2009. Users' perception analysis for sustainable beach management in Italy. Ocean \& Coastal Management, 52(5): 268277.

Marinov, S. 2012. Management decisions in the context of Bulgaria's lifecycle as a coastal tourist destination. Izvestiya 4: 7-16.

Massiani, J. 2013. How to value the benefits of a recreational area? A cost-benefit analysis of the conversion of a Brownfield to a public beach in Muggia (Italy). Review of Economic Analysis 5: 86-102.

Micallef, A., Williams, A.T. 2002. Theoretical strategy considerations for beach management. Ocean \& Coastal Management, 45(4-5): 261-275.

Miller, J.B., Petranov, S. 2000. The first wave of mass privatization in Bulgaria and its immediate aftermath. Economics of Transition 8(1): 225-250.

Mladenova, Z., Angresano, J. 1996. Privatization in Bulgaria. East European Quarterly 30(4): 495-516.

Morgan, M. 1991. Dressing up to survive: Marketing Majorca anew. Tourism Management 12(1): 15-20.

Oh, C.-O., Draper, J., Dixon, A.W. 2010. Comparing resident and tourist preferences for public beach access and related amenities. Ocean \& Coastal Management 53(5-6): $245-251$.

Olson, M. 1965. The Logic of Collective Action: Public Goods and the Theory of Groups, Cambridge: Harvard University Press.

Posner, R.A. 2014: Economic Analysis of Law ( $9^{\text {th }}$ ed.), New York: Wolters Kluwer.

Raybould, M., Lazarow, N. 2009. Economic and Social Values of Beach Recreation on the Gold Coast, Gold Coast: Cooperative Research Centre for Sustainable Tourism.

Randall, A. 1983. The problem of market failure. Natural Resources Journal 23: 131-148.

Sandler, T., Tschirhart, J. 1997. Club theory: thirty years later. Public Choice 93(3): 335-355. 
Scotchmer, S. 1985. Profit maximizing clubs. Journal of Public Economics 27(1): 25-45.

Scotchmer, S. 2002. Local public goods and clubs, in A.J. Auerbach and M. Feldstein (eds), Handbook of Public Economics Vol. 4. Amsterdam: North Holland, 1997-2042.

Stefanov, I. 2015. Free competition should not be restrained by granting beaches. Capital 33: $10-11$.

Tiebout C. 1956. A pure theory of local expenditure. Journal of Political Economy 64(5): 416424.

Tratalos, J.A., Sugden, R., Bateman, I.J., Gill, J.A., Jones, A.P., Showler, D.A., Sutherland, W.J., Watkinson, A.R. 2013. The conflict between conservation and recreation when visitors dislike crowding: A theoretical and empirical analysis of the spatial distribution of recreational beach users. Environmental Resource Economics 55(3): 447-465.

Wade, R. 1987. The Management of common-property resources: Collective action as an alternative to privatisation or state regulation. Cambridge Journal of Economics 11(2): 95-106.

Whitehead, J.C., Dumas, C.F., Herstine, J., Hill, J., Buerger, B. 2008: Valuing beach access and width with revealed and stated preference data. Marine Resource Economics 23(2): 119-135.

Windle, J., Rolfe, J. 2014. Estimating the nonmarket economic benefits of beach resource management in Southeast Queensland, Australia. Australasian Journal of Environmental Management 21(1): 65-82.

Zacarias, D.A., Williams, A.T., Newton, A. 2011. Recreation carrying estimations to support beach management at Praia de Faro, Portugal. Applied Geography 31(3): 1075-1081.

\section{Additional Sources}

Alexander, $\quad$ H. 2013. Greece's Great Fire http://www.telegraph.co.uk/news/worldnews/europe/greece/10007606/Greeces-greatfire-sale.html. (retrieved: 02.02.2016).

Alderman, L. 2015. The Perils of Greece's Privatization Efforts. http://www.nytimes.com/live/greek-debt-crisis-live-updates/the-perils-of-greecesprivatization-efforts/. (retrieved: 02.02.2016).

Act on the Black Sea Coast Spatial Development. http://www.cadastre.bg/en/laws/act-blacksea-coast-spatial-development-amend-sg-1056-dec-2013. (retrieved: 10.11.2015.) 
Ministry of Regional Development 2014. http://mrrb.government.bg/?controller= articles\&id $=5428$ (retrieved: 3.11 .2015$)$.

Pavlova, L. 2015. Inspections Results for Compliance with the Requirements of the Act on the Black Sea Coast Spatial Development in Relation to the Management of Beaches. http://mrrb.government.bg/docs/be3036f60ad9dfa559928aef08f18098.ppt, in addition to http://mrrb.government.bg/docs/9de53f5d7608915ef922a59b394c4fa4.doc, and http://mrrb.government.bg/?controller=news\&id=7120, (retrieved: 22.06.2016).

Olsen, T. 2009. The Politics of Sand. Anchor Pictures, https://vimeo.com/album/2312981 (retrieved: 02.02.2016).

Union of Owners - Sunny Beach 2015. Opinion of NGO Union of Owners - SUNNY BEACH on the Concession of Beaches in Bulgaria. http://www.abtta.com/files/ pages/Stanovishte_za_koncesioniraneto_na_plazhovete-1_22.doc._ (retrieved: 3.11.2015).

Williams, A. 2015. Lebanon Loses Its Beaches to Privatisation. Channel NewsAsia, posted 11 Sep 2015 22:20. http://www.channelnewsasia.com/news/world/lebanon-loses-itsbeaches/2120330.html. (retrieved: 02.02.2016). 